\title{
Work, family and public policy changes in Latin America: Equity, maternalism and co-responsibility
}

\author{
Merike Blofield and Juliana Martinez F.
}

ABSTRACT

Taking account of the substantial increase in female labour market participation that has occurred throughout the Latin American region, this article describes policies adopted with the aim of reconciling work and family responsibilities between 2003 and 2013, and the implications of their design for socioeconomic and gender equity. We look at the cases of Argentina, Brazil, Chile, Costa Rica and Uruguay, five countries which, on the basis of their track records, are the best placed to implement policies to reorganize time, income and services. The empirical analysis indicates, first, that these changes have contributed to socioeconomic equity more consistently than to gender equity. Second, the scale and type of change was found to vary significantly from one country to another. The article concludes by raising a number of substantive questions about the measures, their implementation and effectiveness, and the variations between countries. 


\section{I}

\section{Introduction}

Latin America is undergoing a "silent revolution" (Goldin, 2006) at the intersection between work and family. Seven of every 10 women of childbearing age are in the workforce and increasingly live in femaleheaded — and often single-parent— households. Yet care responsibilities continue to be shouldered primarily by women (ILO/UNDP, 2009; Sojo 2011; Montaño 2010; ECLAC, 2013a). The tensions in gender relations resulting from this combination of change and continuity in work and family are set against a backdrop of deep social inequality (Cornia, 2010; ECLAC, 2011; López-Calva and Lustig, 2010). What have governments done to address these tensions and with what outcomes for inequality? This article explores that question on the basis of policies adopted during the 10 years of economic expansion since 2003 in the five countries in which — as will be discussed later- social policy is, relatively speaking, most developed in the region: Argentina, Brazil, Chile, Costa Rica and Uruguay.

It is worth first discussing the social and policy relevance of addressing tensions between work and family responsibilities. First, the responsibility for care work represents a great barrier to women in terms of accessing the labour market (ECLAC, 2010). In such a highly unequal region as Latin America, this particular gender gap is heavily marked by socioeconomic stratification. The gap in female labour market participation between the richest and poorest quintiles is $30 \%$ on average and has not shrunk since 1990, despite the large rise in women's overall labour market participation. ${ }^{1}$ Given that the odds of overcoming poverty are proportional to the odds of having more than one income in the household

$\square$ The authors are grateful to Ariel Armony, Eleanor Faur, Janet Gornick, Evelyne Huber, Beatriz Magaloni, Esther Mancebo, Carmen Midaglia, Jennifer Pribble, Soledad Salvador, Silke Staab, Juan Diego Trejos, and two anonymous readers at the CEPAL Review. They also thank María Cristina Alcántara, Felipe Sterquino Itaborai and, especially, Diana León for their rigorous and enthusiastic research assistance. Any error of assessment is the sole responsibility of the authors.

1 For example, in Brazil, the gap is almost $40 \%$, with only $46.5 \%$ of women in the lower-income bracket in the labour force versus $84.4 \%$ of women in the higher income quintiles (PNAD/IBGE, 2014; Sorj and Fontes, 2012).
(ILO/UNDP, 2009), women's absence from the labour market worsens poverty and social inequality. Second, women with income of their own are overrepresented among the self-employed and in domestic work; in the latter occupation three quarters of individuals, almost all of them women, had no pension provisions in 2008 (ILO, 2011). Women in the labour market thus have less protection than their male peers - in urban areas only $36 \%$ of women have social security provision, compared with $49 \%$ of men (ILO/UNDP, 2009)—. Third, those who shoulder heavier care burdens have less social protection: in 12 Latin American countries, women with incomplete primary schooling have between 2 and 3.5 more children than those who have secondary schooling or more (ECLAC, 2011, p. 85). In femaleheaded single-parent households, the double burden of singlehandedly providing both care and income worsens the negative consequences of labour informality and lack of social protection.

The situation today enshrines both challenges and opportunities (ILO/UNDP, 2009; Sojo, 2011; Montaño Virreira, 2010; Chioda, 2011). With the right public policies, governments could break the cycle of inequality and promote more inclusive social and economic development. Some measures can achieve more than one objective at a time. For example, it is universally agreed that early education and care services develop human capital and promote equal opportunities. Combined with suitable opening hours and schedules, these services could also support working mothers and fathers. Conversely, without adequate responses to the tensions between work and family responsibilities, socioeconomic and gender inequalities will continue to deepen and work against equity and development in the region.

How much progress has been made in adopting public policies to reconcile work and family responsibilities in those countries that are in the best position to do so? Section II sets forth an analytical framework to examine these changes. Section III explains the methodology and section IV presents the empirical findings. Lastly, section $\mathrm{V}$ concludes with a summary and discussion of the findings. 


\section{II}

\section{Analytical framework ${ }^{2}$}

A broad universe of public policies affect the relationship between work and family responsibilities, whether by action or by omission, ranging from urban planning and public transportation, to social policy per se on issues of leave and care (Monge, 2006). Below, we distinguish between different types of social policy that affect work-family tensions, ${ }^{3}$ then discuss how these maintain or change socioeconomic and gender relations. The section concludes by presenting examples of specific policies aimed at changing initial socioeconomic and gender inequality.

\section{Policies that reconcile work and family}

Whether or not they ultimately have positive or negative impacts from the point of view of socioeconomic and gender equality, measures aimed at reconciling work and family responsibilities can function in three ways: by reallocating time, income or services. Specifically, they enable individuals to alternate time spent at work with time spent on caregiving within the family (Durán, 2004), transfer family care to services partly provided by the State, or regulate the purchase of private care by families. These types of State intervention are sequential, “defamilializing" (Martínez Franzoni, 2008; Orloff, 2009) and regulatory, respectively, ${ }^{4}$ and often addressing workfamily tensions is not in fact their primary purpose; this is the case with preschool childcare services, for example. In addition, as will be illustrated below, each of these types of measure can be addressed from the standpoint of either labour policy or social policy.

- Sequential policies refer to measures that support income during periods - months, weeks or daysspent on caregiving. They include maternity, paternity or parental leave, as well as flextime and part-time work policies. Sequencing can last months and involve many work days (as in maternity

\footnotetext{
2 This analytical framework is developed in greater detailed in Blofield and Martínez Franzoni (2014).

${ }^{3}$ This article refers to work-family tension indistinctly as work-family, and work and family responsibilities.

${ }^{4}$ A first approach to changes in these three types of measures in Latin America (although with a different definition of regulatory measures) was developed by Martínez Franzoni and Camacho (2006 and 2007) on the basis of an adaptation of Durán (2004).
}

leave) or last hours within a single work day or week (as in part-time or flextime measures). With sequential policies, care remains within the family, performed historically by women, although under more recent measures family responsibilities have increasingly been extended to men through paternity and parental leave. ${ }^{5}$

- $\quad$ Policies that defamilialize care refer to transfers and services that shift the responsibility for care provision from families - and specifically from women - to services with some degree of State involvement. These may be provided directly by the State, involve incentives or subsidies for private provision, or mandate employer provision of subsidies, services or both. As with sequential policies, these measures often revolve around mothers and female workers but - as detailed below - have increasingly begun to make men and fathers eligible as well in Latin America (ILO/UNDP, 2009).

- The third category addresses regulations on the hiring of home-based paid care providers specifically, where the household is thus turned into a workplace. These are "regulatory policies on home-based care services". The one-to-one hiring of mostly female personnel for work in familial settings is an alternative to provision in institutional settings, and has different implications for the State's role in measures that defamilialize or commercialize care, since paid domestic work is not usually included in policies for reconciling paid work and family responsibilities.

The main focus of our study regarding the third category is on domestic work that is considered "unskilled", 6 although the analysis can equally be extended to skilled occupations, such as nursing. As with other care occupations, home-based care tends to

\footnotetext{
5 Parental leaves were established first in Europe, specifically in Sweden, in 1974. Paternity leaves came later and were created to encourage men to use parental leave. Both maternity leaves and parental and paternity leave are considerably longer in Europe and in English-speaking countries, except for the United States, which lags behind even by comparison with the poorer Latin American countries. ${ }^{6}$ By "unskilled" we mean that these employees rarely have formal training for their occupations, although they provide services that require a broad range of practical but socially undervalued skills.
} 
be overwhelmingly female and penalized by lower pay than that received by workers in comparably skilled occupations. This penalty derives from three factors: care occupations have historically been seen as extensions of "naturally" female roles; they are perceived as intrinsically rewarding; and, as "sacred activities", they are "above" financial recognition (England and Folbre, 1999).

Insofar as caregiving (whether paid or unpaid) involves an emotional connection between caregivers and those who are being cared for, labour market regulations regarding these occupations are critical to the status of the care providers as workers and to the type of service performed (see for example: Folbre, $1995^{7}$ and Williams, 2010). What makes these occupations distinct is that the workplace and the household overlap and that the bonds between caregivers and care-receivers tend to be more personal, challenging the regulation of these occupations in general, and those based in the employer's home in particular. With caregiving historically associated with a servant culture in many countries, discrimination has been rooted in laws and labour codes, with long working hours and very limited labour protections and benefits.

Domestic or home-based work is, precisely, one of the main ways of resolving the tensions between family and work in Latin America: around $15 \%$ of the economically active female population is employed in domestic services, with a similar percentage of households as employers (ECLAC, 2013b; ILO 2012, pp. 59-60). Weak regulation of this occupation by the State has, in practice, allowed high-income families to reconcile work and family responsibilities at the expense of such reconciliation by these female workers (Blofield, 2012).

Another, more collective form of home-based care (also referred to as family day care) is care in the caregiver's household. While such care has no doubt existed informally throughout time, in the past few decades it has become an object of government funding and regulation as part of social service extension to low-income families.

There are examples of all three types of measure in both labour and social policy. In all three cases, the State may have an impact by action or by omission, leaving the solutions to work-family tensions to family strategies and informal solutions by women, through

\footnotetext{
${ }^{7}$ Folbre (1995) defines care work, whether paid or unpaid, as work that involves connecting to other people and trying to help people meet their needs. Folbre argues that the intrinsic motivation involved in care labour as something people do for a third party poses challenges for markets to organize and pay for care work.
}

unpaid, poorly paid or voluntary work, or by promoting the provision of services through trained professionals hired under formal conditions of employment.

Sequential, defamilializing and regulatory policies are all qualitatively distinct and complementary in workfamily reconciliation. For this reason, more policy in one dimension cannot be expected to make up for less policy in another dimension. Empirical analysis must therefore consider them simultaneously.

\section{Implications for socioeconomic and gender equity}

Depending on how they reallocate time, income support and services, whether by design or through implementation, sequential, defamilializing, and regulatory measures can entrench or alter socioeconomic and gender inequality —as produced by the labour market and the sexual division of labour between women and men-. This work does not evaluate how these measures change the social structure - if indeed they do- but focuses rather on their design.

Let us start by looking at gender inequality. The literature on welfare states and gender relations distinguishes "maternalist" policies from those that promote "social co-responsibility" in caregiving (ILO/ UNDP, 2009). Maternalist measures (Orloff, 2006) recognize the importance of caregiving and exalt "women's capacity to mother" (Koven and Michel, 1993, in Orloff, 2006, p. 4), and thus reward women as the primary and main providers of care. ${ }^{8}$ Here, there is a social recognition of care, but the gender gap in its provision remains intact. Extended maternity leave, tax incentives or monetary transfers for stay-at-home mothers are examples of maternalist measures. They are used as alternatives to greater participation by fathers, the use of services, or both.

We distinguish maternalist policies from policies that establish a "maternalist floor", acknowledging the specific role of women in gestation, giving birth, breastfeeding and establishing early routines and bonds. These are analytical categories, but also thresholds that

\footnotetext{
${ }^{8}$ Historically, maternalist movements "made arguments for gender justice: women should be recognized and compensated by the State for their unique contribution to society - through maternity and childrearing" (Orloff, 2006, p. 10)—. Maternalist arguments can lose ground to a view of care that involves but transcends women. Orloff argues that in European and North American countries, maternalist claims have lost elite and popular support over time, although not always in the direction of more gender equity but rather in the direction of less social equity.
} 
have changed over time. For example, the demarcation of what the International Labour Organization (ILO) considered a minimum maternity leave — and which is taken here to define what we call the maternalist floorhas changed over time. In 1952, ILO set maternity leave at 12 weeks in Convention 103, but by 2000 this had increased to 14 weeks (Convention 183).

A maternalist floor is essential to protect women in their role as mothers. Maternalist policies, however, can affect equity in contradictory ways. Although these policies publicly recognize and support motherhood as a central dimension of women's lives and can thus elevate the status of mothers, they can also reinforce the notion that care is women's sole responsibility. It is an empirical matter to establish which maternalist policies also promote gender equity by levelling the playing field rather than reinforcing the sexual division of labour.

In contrast to maternalism, co-responsibility redistributes care responsibilities, both from families to the State (State co-responsibility) and from women to men (paternal co-responsibility).

State co-responsibility in work-family reconciliation policies not only produces defamilialization through publicly provided or subsidized provision of early childhood education and care (ECEC), but also, and very importantly, requires the provision of full-time care, thus allowing for the use of services by working parents. Public social investment in early childhood education and care services that do not correspond to a typical full-time workday, may promote state co-responsibility in child education but not in work-family reconciliation.

Paternal co-responsibility policies promote sharing of caregiving by incentivizing fathers' involvement. This makes it possible to alternate income-generating and caregiving responsibilities between women and men (Fraser, 1997). This "feminization of the male life cycle" (Esping-Andersen, 2009, p. 99) generally takes the form of sequential policies that enable the reorganization of gender roles between mothers and fathers, without undermining pay or job continuity.

By shifting more responsibility for care to the State and to fathers, co-responsibility policies have the capacity to reduce gender inequities in the burden of care. The extent to which they actually do so is a matter for empirical analysis. The Swedish experience shows that paternity leave which is not transferable to the mother promotes fathers' involvement in childcare more than does parental leave, for which both fathers and mothers are eligible. Both paternity leave, consisting of a few days to support the mother, and parental leave, have been established very recently in Chile and Uruguay, so knowledge of their effects in terms of reducing gender inequality is still very incipient.

In terms of socioeconomic equity we follow EspingAndersen's (1990) distinctions between eligibility based on needs, contribution, or citizenship. The implications of these criteria vary depending on the point of departure: relative social equality, low poverty rates and basically formal labour markets, or the opposite, as in Latin America, where highly informal labour markets limit the scope of contribution. Here eligibility mechanisms must be more heavily based on citizenship and need than in developed countries. ${ }^{9}$

Furthermore, it may be observed that policies based on contributions through formal employment tend to restrict benefits to those making regular contributions as well as their dependents - often even segmenting benefits between the former and the latter-. This mode of eligibility applies primarily to middle- and upperincome groups of the population, therefore reinforcing socioeconomic inequities. ${ }^{10}$ These policies also tend to reinforce inequities between groups within the formal labour force; for example, workers on fixed-term contracts and paid domestic workers may not legally have access to the same rights.

Taking into account the prominence of informal relations in Latin American labour markets (in temporary and domestic work, for example), the question is whether policies extend protections beyond formal employment to a broader scope of wage workers, self-employed workers, or both. ${ }^{11}$ We also assess whether policies move beyond an individual's formal labour status to a basis in citizenship or need. We thus evaluate whether workfamily policies -whether sequential, defamilializing or regulatory, and maternalist or pro-co-responsibility — alter or reproduce the initial, labour-market stratification and therefore also enhance socioeconomic equity. ${ }^{12}$

Second, informality pervades care arrangements, either through the informal hiring of domestic workers or through female unpaid work. Without government

\footnotetext{
9 Nevertheless, contributory social protection has more relative coverage and social investment than non-contributory programmes.

10 For a discussion of the relevant cases where universalism has been built around contributory policy, see Martínez Franzoni and Sánchez-Ancochea (2013).

11 In Latin America labour and social protections reach workers in various degrees, so that there is a continuum from the most formal to the most informal arrangements among wage workers as well as the self-employed. Rather than making up an informal "sector", informality thus cuts across the labour market.

12 See Pribble (2013) for a broader discussion of equity-enhancing social policies.
} 
intervention, the care burden tends to fall particularly heavily on low-income women. In other words, degrees of familialization in care (Martínez Franzoni, 2008; Orloff, 2009) differ by income levels. The higher the family's income, the greater the capacity to transfer much of the burden of domestic work to lower-income women hired for that purpose and avoid women having to negotiate the sharing of care responsibilities with their male partners. Conversely, the lower the household income, the fewer the options to outsource domestic and care work.

Given the interactions between socioeconomic and gender inequalities, it would be wrong to subsume one type

\section{III}

\section{Methodology}

Below, we analyse types of paid leave for birth, full-time childcare services and the levelling of the rights of paid domestic workers with the rest of the workforce. These policies do not, of course, represent the entire universe of sequential, defamilializing and regulatory policies, but are nevertheless emblematic.

The cases examined correspond to five Latin American countries that are in the best position, relatively speaking, to respond to changes in families and labour markets in the region: Argentina, Brazil, Chile, Costa Rica and Uruguay. This is the group of countries with modest social gaps (Filgueira, 2011), comparatively formal labour markets and greater social investment. Accordingly, they are generally considered to have the same social policy regime-Statist (Martínez Franzoni, 2008) or advanced (Huber and Stephens, 2012). They have highly institutionalized political systems and greater State capacity (Pribble, 2013), and have reached a more advanced stage of the demographic transition (ECLAC, 2010).

We compare federal policies in place in 2003 and 2013 across these countries and over time. It is important to be aware that a large gap can exist between measures formally in place and their implementation. Nevertheless, the adoption of these measures is in itself indicative of existing policy priorities, and understanding of inequality under another; we must instead examine their interaction across distinct policy initiatives. The three types of policy — sequential, defamilializing, and regulatorymay have various implications for socioeconomic and gender stratification. Empirically speaking, in terms of gender equity we attempt to establish whether specific measures promote a maternalist floor, maternalism, or co-responsibility. Regarding socioeconomic equity, we address whether or not protection extends beyond wage work and contributory mechanisms to cover ownaccount or temporary workers, or on the basis of need or citizenship. the gap calls for more comprehensive assessments that include the degree of implementation of the changes in question. Legislation and executive measures that have been discussed but not adopted are not included, nor are collective agreements (which are important in Uruguay, Brazil and Argentina, in particular) or state-level legislation - which is particularly prominent in the two federal countries analysed (Argentina and Brazil) — that goes beyond the federal minimum.

The empirical evidence used comes from primary and secondary sources. The first include laws, executive decrees and policy papers, executive committee or congressional reports and interviews, as well as press articles. Secondary sources include country analyses, several of which take a sociological approach or are intended to provide assessments or policy inputs. ${ }^{13}$

\footnotetext{
13 There is an interesting and growing body of literature on the subject for the five countries. For example, for Argentina, see Faur (2011); Faur, Esquivel and Jelin (2012); Gherardi, Pautassi and Zibecchi (2012) and Rodríguez and Pautassi (2014); for Brazil, see Hirata and Araujo Gimarães (2012), and Sorj (2013); for Chile, see Bentancor and De Martini (2012), and Staab (2012) (the latter with an explicit focus on policymaking); for Costa Rica, see Román and Morales (2010); Sauma (2012); for Uruguay, see Aguirre and Ferrari (2014) —focusing strictly on policy adoption-; Batthyany, Genta and Perrotta (2012), and Salvador (2013).
} 


\section{IV}

\section{Empirical evidence: work-family policies in 2003 and 2013}

Below, we examine the empirical evidence on paid leave for childbirth, early childhood care and education and the rights of paid domestic workers, as cases of sequential, defamilializing and regulatory policies, respectively. The findings show that more changes have occurred in care services and the regulation of paid domestic work than in leave associated with paid employment.

The broadest legal changes in this last category have occurred in Chile and Uruguay, and affect both eligibility and length of leave. In the other three countries, groups of female workers have gained eligibility for maternity leave, either through legal rulings (Brazil and Costa Rica) or legislative reform (Argentina).

Early childhood care and education services have undergone changes to varying extents in all the countries. In general, more progress has been made in promoting socioeconomic equity than in paternal co-responsibility.

\section{Sequential measures: increased maternalism and socioeconomic equity}

How much have employment-based paid leaves changed and how? Figure 1 shows the duration in weeks of paid maternity, paternity and parental leaves in the five countries in 2003 and 2013. All the leaves analysed correspond to a full salary -although sometimes with a ceiling, as in Chile- but they differ in the source of financing (from social security in Argentina, Brazil and Uruguay; from a combination of social security and employers in Costa Rica; and from the national budget in Chile). The best scenario for socioeconomic and gender equity is when leaves do not carry a direct cost for employers. ${ }^{14}$

Paid maternity leave was established in the countries' labour codes in earlier decades, and by 2003 ranged from 12 weeks in Uruguay to about 18 weeks in Chile. In 2003, paternity leave was zero in Costa Rica and Uruguay, 1 day in Chile, 2 days in Argentina and 5 days in Brazil (enshrined in the Constitution of 1988). Except

\footnotetext{
14 Leaves that do represent a direct cost for employers not only discourage the hiring of women, but also affect smaller firms more and so are regressive in terms of the production structure. For data and analysis on this point for the region overall, see Pautassi and Rico (2011).
}

for Argentina, in all the countries women continue to accumulate pension entitlements during maternity leave.

Figure 1 distinguishes between measures corresponding to the maternalist floor (equivalent to the ILO threshold of 14 weeks, shown by a line), maternalist measures (above the line), and measures that promote co-responsibility either through non-transferable leave for fathers (paternity leave), or through leaves that are shareable between mothers and fathers (parental leave).

In 2003 maternity leaves were at least the length of the maternalist floor, except in Uruguay and Argentina. Uruguay provided two weeks less, and Argentina - with a leave of 90 days - slightly more than a week under the 14 weeks established by ILO.

During this period, leaves changed considerably in Chile and Uruguay. Already by 2003 Chile had the longest maternity leave of the five countries and the reform of 2011 (Law 20.545) added a further three months. That reform also extended paternity leave (from 3 days to 5) and allowed fathers to use up to half of the final three months of postnatal leave. The reform accordingly promoted a combination of marked maternalism with timid progress in paternal co-responsibility. ${ }^{15}$

In Uruguay various changes were made to the leave scheme and November 2013 brought a comprehensive reform for the private sector (Law 19.161). As a result, in the private sector maternity leave increased from 12 to 14 weeks. Paternity leave was extended as well, from 3 consecutive days in the private sector and 10 working days in the public sector to a further 10 consecutive days in the private sector, for both wage workers and independent workers paying into Uruguay's Social Security Bank (Banco de Previsión Social, BPS). ${ }^{16}$ The extension took effect immediately for maternity leave, but more gradually for paternity and parental leave.

Previously, public sector paternity leave had been 3 days since the reform of 1989 (Law 16.109) and 10 days from 2008 (Law 17.930), when private sector workers also gained another 3 days of paternity leave. To the

\footnotetext{
15 See Lupica (2013) for an analysis of the process by which the proposal was prepared.

16 Self-employed in the formal sector who pay social contributions through profession-related funds are not included.
} 
FIGURE 1

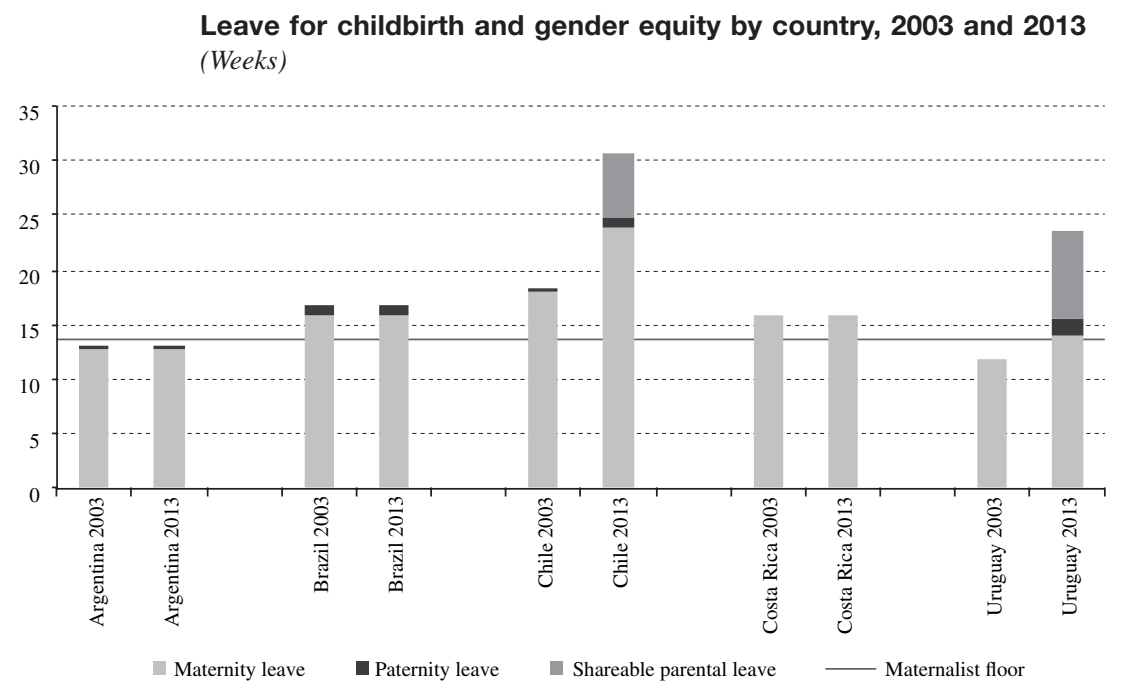

Source: prepared by the authors, on the basis of legislation in the respective countries and data from R. Ray, J. Gornick and J. Schmitt, "Who cares? Assessing generosity and gender equality in parental leave policy designs in 21 countries", Journal of European Social Policy, vol. 20, No. 3, Sage, 2010.

Note: the duration of paternity leave was registered in relation to a unit of a 7-day week. For Uruguay, paternity leave was estimated on the basis of an 8-week maternity leave (Law 19.161, article 2).

3 consecutive days financed by the employer, the 2013 reform added 3 more days in 2014 financed by the Social Security Bank, increasing to 7 more in 2015 and 10 more in 2016. Accordingly, the 13 consecutive days in the private sector are more or less equivalent to the working days of leave in the public sector (depending on whether public holidays occur during the leave). ${ }^{17}$

In 2016, parental leave will allow the mother or the father to work a half-day after the 8-week maternity leave is over, until the child is six months old. This part-time leave will last for up to 4 months or, for comparison purposes, 8 weeks full-time, as shown in figure 1 (following Ray, Gornick and Schmitt, 2010).

The reforms adopted in Chile and Uruguay have different implications for gender equity. Maternity leave was extended beyond the maternalist floor in Chile, and brought up to that threshold in the private sector in Uruguay. Paternity leave is twice as long in Uruguay as in Chile, and in Uruguay it is financed mainly by social security and to a lesser extent by the employer, while in Chile and Brazil it is financed by the employer. In sum, the change favours parental co-responsibility more in Uruguay than in Chile, in principle. At the other extreme, Argentina was the only one of the five countries that

17 See Salvador (2013) for an estimate of the costs of the reform in Uruguay, which is also methodologically useful for the other countries. had yet to reach the ILO standard maternalist floor in 2014. What is more, apart from the cases of Chile and Uruguay, and despite draft legislation aimed at extending paternity leave to between 2 and 4 weeks in Argentina, Brazil and Costa Rica, paternity leaves continue to be minimal.

Given the prevalence of labour informality, employment-based leaves have been particularly unequal from a socioeconomic perspective. Since maternity leave is by far the more substantial, figure 2 shows eligibility criteria in each country in 2003 and 2013. Specifically, it shows whether only some female wage workers, all female wage workers or all female workers, including the self-employed, are eligible.

In 2003, in Chile and Argentina only some female wage workers were eligible for maternity leave, leaving out precisely those who were socioeconomically more vulnerable. In Chile only those with employment contracts were eligible, which were mostly those in the upper income quintiles (Pribble, 2006, p. 90), although domestic workers with contracts were included in 1998. Domestic workers were excluded in Argentina (where they represent $17 \%$ of the female urban workforce). In Brazil, Costa Rica and Uruguay all female wage workers were eligible, including, in the case of Brazil, independent and rural seasonal workers. This last group does not need to show social security contributions to qualify for maternity leave with benefits equivalent to the minimum 


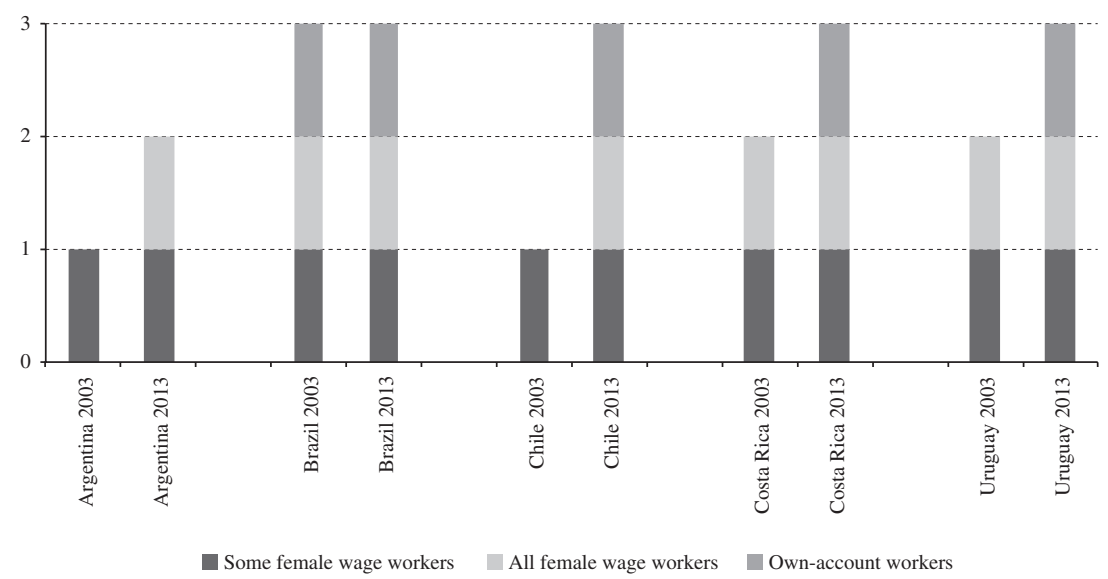

Source: prepared by the authors, on the basis of legislation in each country.

wage. Since 2003, all five countries have changed the eligibility rules towards greater socioeconomic equity; in Costa Rica and Brazil through legal action and in the other three countries by legislative reform.

In Argentina, a legal reform adopted in 2013 (with implementing regulations adopted in April 2014) extended maternity leave to domestic workers, making all female wage workers eligible. ${ }^{18}$ In Brazil, a 2012 ruling by the supreme labour court extended the right to maternity leave to workers on temporary contracts. In Chile, the 2011 parental leave reform extended maternity leave to all female wage workers, seasonal and independent workers. Costa Rica made insurance mandatory for independent workers as part of a deal on pensions between the government, chambers of commerce, unions and other organizations. ${ }^{19}$ Although the agreement initially included only the services sector, in 2004 a ruling by the Constitutional Court extended it to monetary transfers and, accordingly, to maternity leave. Seasonal workers are considered wage workers, and hence their insurance is mandatory. However, there have been obstacles to adapting the conditions of insurance, for example, for seasonal rather than monthly contributions. In Uruguay,

18 Law 26.844 with implementing regulations in executive decree 467 of 2014.

${ }^{19}$ In 2008, a pension reform recognized and provided compensation for time mothers devote to raising children, increasing their probability of eligibility for an old-age pension in the future. the legislature extended maternity leave to some insured self-employed women in 2013. ${ }^{20}$

Informal female workers who do not contribute to social security - generally a large proportion of the lower-income quintiles - are excluded from these eligibility criteria, except for rural workers in Brazil. ${ }^{21}$

\section{Defamilializing measures: advances towards State co-responsibility with socioeconomic equity in early childhood care and education}

Below we examine national policies on early childhood care and education, principally for children aged 0 to 3 years, and tangentially for those aged between 4 and 5 -the two age groups targeted by early childhood care and education services and preschool education-. Depending on their opening hours and coverage of lowincome sectors, care services can promote both State co-responsibility and socioeconomic equity.

Preschool education tends to reflect concerns of human capital formation more than early childhood care

\footnotetext{
20 As pointed out by Soledad Salvador (2014), in fact all benefits (paternity and parental) are extended to men and women who pay into the Banco de Previsión Social (not independent funds such as profession-related funds), business-owners with up to one dependent, and the self-employed. Those with dependent workers are reported as employers.

21 Women in this position can be eligible for other cash transfers as mothers rather than as workers, mainly through conditional cash transfer schemes for children, pregnant women or both.
} 
services. Services for children aged 0-3 give a closer picture of governments' commitment to work-family balance - i.e. State co-responsibility— through services that partially defamilialize care and provide full-time service coverage. This is also the age group for which there is greatest social reticence regarding mothers combining motherhood and paid work and, in general, any outsourcing of care outside the household.

Argentina, Brazil and Chile have had legislation obliging large firms to provide some childcare arrangements since before 2003. ${ }^{22}$ These arrangements depend on the number of female workers in the firm, are limited to mothers (fathers are not eligible) and were created to allow for breastfeeding during the legally established period. In Chile, employers with 20 or more female workers must provide a day-care service for children under age 2. In Brazil, companies with 30 or more female workers must provide day care for babies up to 6 months old (i.e. for two months, between the end of the obligatory maternity leave and the end of the six-month breastfeeding entitlement). In Argentina, employers with 50 or more female workers have been legally obliged to provide a day-care service since 1970 . However, although this law is nominally in force, compliance is difficult to oversee because implementing rules have not been adopted for it.

This legislation has not changed in the period under consideration. Insofar as having a facility is better than having none, the legal framework of workplace childcare is indicative of some degree of State (if not paternal) coresponsibility. However, since the services are limited to a small group of working mothers in the formal sector, they are not particularly favourable for socioeconomic equity. In addition, as maternalist measures targeting only female workers, they can disincentivize the hiring of women of childbearing age, or of more women than the legal threshold above which the law obliges firms to provide workplace childcare facilities.

The changes we see in public service provision have to do with extending early childhood care and education services. Table 1 provides an analysis of the extent of full-time care in the framework of national programmes for children aged 0-3 years. In each case we determine eligibility criteria (fundamental for socioeconomic equity), and the existence of coverage goals and data. The last two indicators serve to assess governments' commitment to State co-responsibility in childhood care

22 Law 20.744 (1974) in Argentina; article 389 of the Labour Process Code, in Decree-Law 229 of 1967 in Brazil; and article 203 of the Labour Code, in Law 19.408 in Chile. and education services for children aged 0-3 years, and whether they promote socioeconomic equity.

With the exception of Argentina, in 2003 the countries included here all had national programmes for early childhood care and education for children aged 0-3. In Brazil, Chile and Uruguay these programmes - which will be discussed in more detail later (childcare centres, National Board for Nursery Schools (JUNJI), Fundación Integra and Child and Family Assistance Centres (CAIF), respectively)— had explicit eligibility criteria. By contrast, in Costa Rica children were eligible for Education and Nutrition Centres/Integrated Centres for Childcare (CEN-CINAI) on the basis of economic need, but this criterion was applied fairly discretionally and varied depending on the demand at each centre, becoming more targeted where demand was heavier. Brazil and Uruguay had set coverage targets, quite ambitious ones in the first case. In socioeconomic terms, eligibility criteria for early childhood care services varied widely from no standard criteria in Costa Rica to universal eligibility in Brazil based on the 1988 Constitution.

By 2013, Argentina had established a national programme of Child Development Centres (CeDIs) under Law 26.233 of 2007. By this time, none of the national programmes in the five countries restricted children's eligibility on the basis of the mother's employment status. However, several programmes afforded priority, in different ways, to the children of full-time working mothers. This was the case of Chile's Crece Contigo (ChCc) scheme, and the expansion of coverage for 0-3-year-olds in Uruguay. In addition, in the five countries examined, a high proportion of services operated parttime. ${ }^{23}$ Clearly, these programmes' contribution to State co-responsibility is conditioned by the opening hours of facilities: full-day services that are compatible with formal working hours and that provide greater social protection represent greater State co-responsibility.

Looking at the situation by country, in Argentina, a reform to education legislation in 2006 established services from the age of 3 years as well as kindergartens for children aged between 45 days and 2 years (Law 26.206), but these services were not implemented. However, Child Development Centres (CeDIs) were established for children from low-income households, provided by the State itself and by non-governmental organizations (NGOs) (Faur, 2011).

In Brazil, the constitutional right to early education has been guaranteed since 1988, including for children

\footnotetext{
${ }^{23}$ Empirical evaluation of centres and users by full-time or part-time provision exceeds the scope of this analysis.
} 
TABLE 1

State co-responsibility: adoption of a full-time national programme for early childhood care and education, ${ }^{a}$ between 2003 and 2013

\begin{tabular}{llll}
\hline Country & Programme & Eligibility criteria & $\begin{array}{l}\text { Existing coverage, goal and hours } \\
\text { around } 2010^{\mathrm{b}}\end{array}$ \\
\hline Argentina & $\begin{array}{l}\text { National Education } \\
\text { Law (2006) }\end{array}$ & $\begin{array}{l}\text { Children aged } 45 \text { days or over (services } \\
\text { outside the formal education sector } \\
\text { are recognized) }\end{array}$ & $\begin{array}{l}30 \% \text { at age } 3 ; 67 \text { 141 children aged } 0-2, \\
\text { equivalent to } 3.5 \% \text { of this age group }\end{array}$
\end{tabular}
are recognized)

For children aged 0-3 there were no specific measures until the creation of ceDIs with need-based criteria

Child Development Centres Economic need (CeDIs) (2007)

Brazil

Education Guidelines and Bases Law (1996, financing since 2007)

Chile

Chile Crece Contigo (chcc)

Costa Rica

Day Care and Integral Development Centres (CECUDI) (2010)

Uruguay
National Care System (2011)
Universal (in the framework of the education system)

Expansion of childcare centres known as "créches"

$60 \%$ most vulnerable of the population (in the framework of care services outside the education system)

Takes the form of the $\mathrm{CHCC}$ programme

Need-based, aiming for universal coverage (in the framework of care services outside the education system) CECUDI scheme expanded with new and existing services

Need-based aiming for universal coverage (can be outside the education system) Expansion of Child and Family Assistance Centres (CAIF) and supply-side subsidies
No data; target unknown

In $2010,18.4 \%$ of children were covered, with an average of 8 hours per day (of the target set in 2001 of $50 \%$ of children aged 0-3, which was renewed in 2010)

In 2010, coverage was 212000 children, meeting the target of creating 113000 additional places

Coverage increased from 7500 children aged $0-6$ in 2010 to 15000 children in 2013; in keeping with target to increase coverage by 8000 children

In 2009 coverage was $13 \%$ for children under 1 year, $26 \%$ for 1-year-olds, $29 \%$ for 2-year-olds and $47 \%$ for 3 -year-olds (a total of 41216 places in 2008 of the target of 43000 for 2009)

Source: Argentina: Ana Malajovich, "La exclusión de los más vulnerables: Deudas educativas con la primera infancia", Voces en el Fénix, No. 3, Buenos Aires, University of Buenos Aires, 2014; Lea Waldmann and others, Servicios de atención a niños y niñas de 45 días a 36 meses, Buenos Aires, United Nations Children's Fund (UNICEF), 2011; Brazil: National Education Plan 2001 and 2011-2020; Costa Rica: Government of Costa Rica, "Plan Nacional de Desarrollo 2010-2014", María Teresa Obregón Zamora, San Jose, December 2010; Chile: Ministry of Planning/Ministry of Health (mideplan/Minsal), Cuatro años creciendo juntos. Memoria de la Instalación del Sistema de Protección Integral a la Infancia Chile Crece Contigo 2006-2010, Santiago, Chile, 2010; Uruguay: Comité de Coordinación Estratégica de Infancia y Adolescencia, "Estrategia Nacional para la Infancia y la Adolescencia (ENIA) 2010-2030. Plan de Acción 2010-2015", Working Paper, Montevideo, 2010; Ana Cerutti and others, Plan CAIF, 1988-2008, Montevideo, October 2008; and Soledad Salvador, "Hacia un Sistema Nacional de Cuidados en Uruguay", Montevideo, Economic Commission for Latin America and the Caribbean (ECLAC), 9 December 2010.

${ }^{a}$ For children aged $0-3$ years.

${ }^{\mathrm{b}}$ Where hours are not indicated, the proportion correspond to full-time services is unknown.

under age 1, and in 1996 this right became law. However, what has progressed during the period under analysis is the fulfilment of this legal framework: in 2006, responsibility for early childhood care and education services passed from the Ministry of Social Development and Hunger Alleviation to the Ministry of Education, while implementation remained the responsibility of municipalities. The main challenge since then has been getting the various levels of government to enforce this right and, from the point of view of work-family reconciliation, getting centres to provide full-day services. Current coverage is far from guaranteeing that sort of provision: in 2001, the National Education Plan set a coverage target of $50 \%$ for children aged 0-3 for 2010. However, in 2010 coverage was less than $20 \%$ and the 10 -year plan set the $50 \%$ target again, this time for 2020. The State performed better in terms of hours of service in childcare centres (créches); in 2012 daily hours averaged eight, compared with less than five in preschools (for children aged 4 and 5) (Ministry of Education (MEC)/ National Institute for Educational Studies and Research (INEP)). 
In 1994, Chile had a relatively limited programme for low-income working mothers, who had to show formal contracts and document their low income to qualify for JUNJI/Integra services (Pribble, 2006, p. 91). In 2006, the Administration of Michelle Bachelet created the programme Chile Crece Contigo (ChCC) to coordinate and broaden existing services for children of preschool age, especially among the lower income quintiles. In 2009, Law 20.379 enshrined "the right to a full-time créche and kindergarten place for the children of mothers who are working, studying, or looking for work; and the right to a part-time kindergarten place with no further requirements regarding parents' activities" (Staab, 2012, p. 313) for the 60\% most economically vulnerable proportion of the population.

Between 2006 and 2010, places in ECEC centres under the ChCC umbrella more than doubled, from almost 97,000 to over 210,000 (MIDEPLAN/MINSAL, 2010, pp. 59-60). With the change in government in 2010 the expansion of coverage came to a halt and there were no longer clear goals for increasing coverage.

In Costa Rica, the Education and Nutrition Centres/ Integrated Centres for Childcare (CEN-CINAI) programme was formalized in the 1970s and had changed little by 2010. Since then, the Government of Laura Chinchilla has created the universal National Childcare and Development Network, which brought together existing care modalities (Sojo, 2011) and created a new municipal facility, Day Care and Integral Development Centres (CECUDI). This network provides universal services for children aged 0-12, but channels public subsidies in a targeted manner (IMAS, 2013). In 2013 the system had explicit eligibility criteria, as well as coverage expansion targets - relatively modest ones, to include 8,000 children in full-time services (Government of Costa Rica, 2010)including for the 0-3 age range.

In Uruguay, Child and Family Assistance Centres (CAIF) have provided services to 0-4-year-olds from low-income households since 1988 (Pribble, 2006; Salvador, 2010, p. 32). Families qualify on the basis of social vulnerability and children's ages (CAIF, 2008). In 2011, the Government of José Mujica announced the creation of a National Integrated Health System for children, the older adult population and persons with disabilities. After solid progress in defining the system's main components, the project is currently in a budgetary and implementation hiatus. Under this system, the government plans to broaden eligibility criteria for early childhood care and education services, first by completing coverage for all children from the lowest income quintile. In the meantime, the work of the CAIF centres has been complemented with public subsidies from the Ministry of Social Development, to enable children to attend existing private kindergartens.

Broadening public preschool services has taken place in parallel with changes in provision for early childhood in schools. As in the case of primary education, this has been mainly on a part-time basis. Successive expansions at the preschool level have occurred by lowering both the age at which children can start, and the age at which they must start. All the countries have taken steps towards universalizing access. However, the increase in coverage has come about chiefly in part-time facilities and has thus not expanded co-responsibility in work-family reconciliation, although it has increased co-responsibility in preschool education per se.

Preschool education from the age of 3 has been a right in Uruguay since 1995, but was initially obligatory only from the age of 5, and later from age 4 (Pribble, 2013, p. 89; Mancebo, 2012; Salvador, 2014). Costa Rica legislated on the gradual lowering of universal preschool education from age 5 to age 4 in 1997 , although it was still not obligatory until age 5. In Argentina, attendance in preschool education from age 5 has been obligatory since 1993 (Pautassi and Zibecchi, 2010, pp. 18-19). In 2006, a reform legislated that free public preschool education would be made gradually available from the age of 4 (Faur, 2008, pp. 56-57), although still not obligatory until age 5. In Chile, universal preschool education has begun at age 4 since 1997, but is not obligatory until the age of 5. In Brazil, preschool education begins at age 4 and in 2009 it was established that attendance from that age would become obligatory in 2016.

\section{Regulatory measures: bringing the rights of paid domestic workers into line with the rest of the workforce}

Throughout the region, paid domestic work is a key strategy for women and families to reconcile paid work and family responsibilities (ECLAC, 2013b), and is therefore a useful proxy for examining the way governments regulate occupations associated with care in general. Historically, social and labour regulation has legally discriminated against domestic workers. Since most of them are women who are socioeconomically vulnerable, more equitable treatment of paid domestic workers is an indicator of greater socioeconomic equity. In turn, since two of the rights at stake are working hours and maternity leave, the analysis also shows progress in State co-responsibility. 
In particular, it is useful to establish what reforms have been implemented to ensure that domestic workers have the same rights as the rest of the employed population (Blofield, 2012). Figure 3 depicts the labour rights of domestic workers enshrined in national labour legislation in 2003 and 2013. The comparison includes social protection (social security and maternity leave) and labour regulation (minimum wage, vacation and a category referring to other discriminatory clauses). A value of 6 denotes legislation that affords domestic workers the same rights as the rest of the employed population.

As shown in figure 3, in 2003 the labour codes of all five countries discriminated against domestic workers: their working day and week were both longer than in other occupations. In Uruguay in 2006, in Costa Rica in 2009 and in Argentina and Brazil in 2013, these rights were brought into line with the general labour code. ${ }^{24}$ As of mid-2014 — and despite a draft reform in the executive - only Chile maintains discriminatory clauses.

The length of the working day has been the most difficult right to bring into line under the law, reflecting a combination of discriminatory attitudes, both gendered and socioeconomic in nature. On the one hand, domestic and care work is seen as an activity that women perform because they are women. Since it is not considered real

24 These latest reforms took place after ILO adopted a convention on the matter in 2011. work, and even less, work that requires qualifications, it is often thought that the regulations can dispense with the standards and limits that exist for other occupations. On the other hand, women who perform these tasks are supposed to be available unconditionally to attend to the high-income families who hire them. Domestic workers' own family responsibilities are not taken into account in their condition as "servants" (Blofield, 2012).

Figure 4 compares the legal working week for domestic workers with that of the rest of the economically active population in 2003 and 2013. The columns show the differences in the hours of each occupation. In 2003, the difference averaged more than 20 hours in all the countries. ${ }^{25}$ In 2006 in Uruguay and in 2009 in Costa Rica, these working hours were equalized. In 2013, Argentina and Brazil did the same. In 2005, the gap in the working week of Chilean domestic workers widened with respect to other workers, from 24 to 27 hours (with working weeks of 72 hours in comparison with a reduction from 48 to 45 hours for other workers).

From the perspective of work-family reconciliation, a stronger guarantee of domestic workers' labour and social rights is indicative of greater State co-responsibility

25 In Brazil and Uruguay maximum working hours are not specified. The regulation suggests that these workers are expected to be available except for meal and rest times. Accordingly, their daily hours have been calculated at 16 .

FIGURE 3

\section{Co-responsibility and socioeconomic equity: changes in labour rights} of domestic workers in labour codes, 2003 and 2013

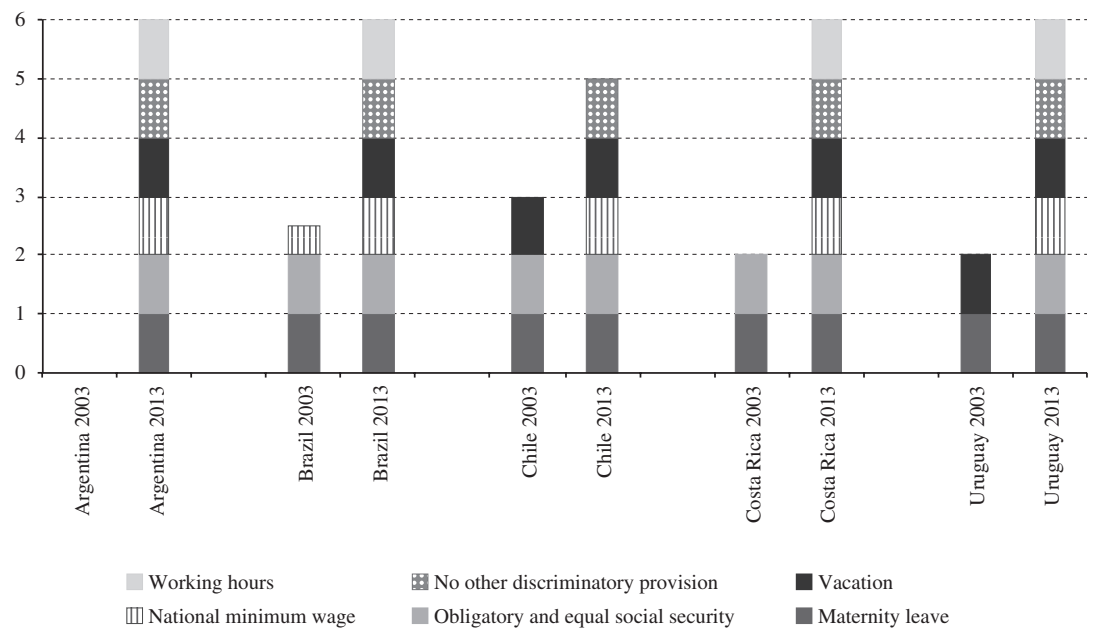

Source: prepared by the authors, on the basis of Merike Blofield, Care Work and Class: Domestic Workers' Struggle for Equal Rights in Latin America, University Park, Pennsylvania, Penn State Press, 2012, and updated as of 2013 on the basis of the national legislations of the respective countries. 
FIGURE 4 Difference in maximum weekly hours between domestic workers and workers in general, 2003 and 2013

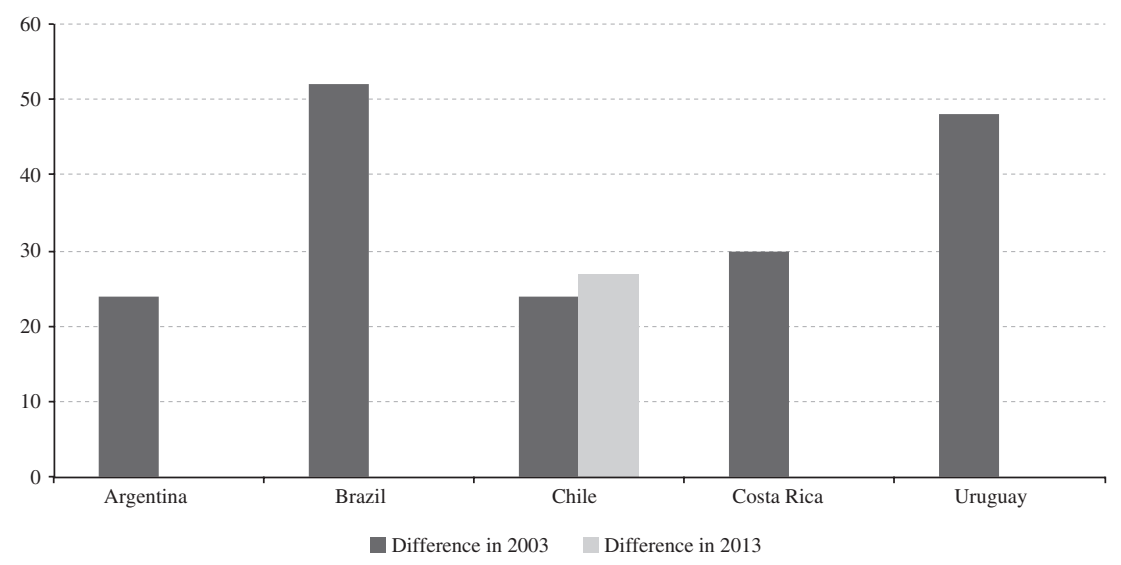

Source: prepared by the authors, on the basis of Merike Blofield, Care Work and Class: Domestic Workers' Struggle for Equal Rights in Latin America, University Park, Pennsylvania, Penn State Press, 2012, and updated as of 2013 on the basis of the national legislations of the respective countries.

in service procurement, with direct effects on workfamily reconciliation for the workers themselves. The socioeconomic status and gender of domestic workers, the great majority of whom are women, are inevitably intertwined, so the way in which the State addresses their labour conditions indicates the value it affords to the two types of equity. Any measure that improves conditions for domestic workers promotes both dimensions of equity.
Because guaranteeing domestic workers' rights makes this means of work-family reconciliation more expensive for families who pay for this still highly informal work, it can worsen work-family tensions for those families in the short term. Yet, in the medium and long term, formalizing domestic workers' labour conditions can foster collective efforts towards more institutionalized sequential and defamilializing measures.

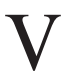

\section{Analysis and conclusions}

Socioeconomic inequalities have eased slightly in Latin America in the past 10 years. However, the gap in labour participation between poor and non-poor women changed little between the start and the end of the first decade of the 2000s. Because socioeconomic and gender inequalities are closely linked, reducing any type of inequality necessitates tackling the work-family balance through public policy. Also, not all policies can promote socioeconomic and gender equality simultaneously. In order to establish how much and what type of progress has been made, this article discussed changes in employment-based leaves, care services and the labour protection of domestic workers as indicators of sequential, defamilializing and regulatory policies, respectively. This article's main contribution has been to break down and analyse these types of reconciliation policies to show in a simple and comparative manner how much and what type of change has occurred between 2003 and 2013 in the five countries examined, and what the implications are - from the perspective of policy design rather than policy implementation - for inequality.

The evidence on policy adoption shows varying degrees of change in the different countries and policy types. In the national comparison, in 2003 Argentina and Chile had less inclusive work-family policies, comparatively speaking. By 2013, Chile and particularly Uruguay had made reforms to all three types of policy, whereas Argentina, at least with regard to the policies 
examined and by comparison with the other countries, had made no changes. Both in 2003 and in 2013, Brazil and Costa Rica show a mixed performance between policy types.

The comparative analysis also shows the type of change that countries have sought to achieve. In the five countries measures have been taken to extend maternity leave to the most vulnerable groups of workers, broaden expectations of early childhood care and education services as a right for children, and regulate paid domestic work. These are very important measures for lower-income women and thus positive from the point of view of public policymaking for socioeconomic equity.

The greater protection of paid domestic work indicates to increased State co-responsibility in workfamily reconciliation insofar as the State acts upon the conditions in which paid care services are procured within the household. Over the long run, from the point of view of the families hiring this type of labour, such measures should also create the conditions to push the State to design better sequential and defamilializing measures.

Early childhood education and care services have expanded State co-responsibility in workfamily reconciliation where they are provided on a full-time basis. It is notable that in all five countries employers' obligation to provide childcare services has remained unchanged.

Lastly, reforms in employment-based leave have been mixed. The governments of all the countries have adopted measures aimed at increasing socioeconomic equity. Two countries, Chile and Uruguay, have taken steps towards paternal co-responsibility by extending paternity leave (which, although still short, is twice as long in Uruguay as in Chile) and creating parental leave (though with different modalities in the two countries). At the same time, the Chilean reform is comparatively maternalist, insofar as its maternity leave reinforces the idea that children are mainly a maternal responsibility. In the other three countries paternity leaves have been on the agenda, but have not been adopted.

Measures aimed at guaranteeing a maternalist floor beyond maternity leave include the child benefits established in Chile and the contribution to pensions for each live birth in Uruguay, which by recognizing the differentiated role of women aim to level their socioeconomic status with that of their male peers.

The analysis conducted here indicates that, as a general rule, policies continue to treat the care of small children as the responsibility of mothers. Sequential measures (such as maternity leaves), defamilializing measures and the regulation of care work have all tended to make more progress in promoting socioeconomic equity than in promoting paternal co-responsibility, although the recent reforms in Chile and Uruguay indicate a small but qualitative change in this direction. Although the need for full-day early childhood care services is increasingly on the agenda in most of the countries, performance in terms of State co-responsibility is still hard to assess.

The foregoing comparative analysis of change and continuity has left three types of questions still to be addressed. First, how effective are these measures at the implementation stage? Second, what capacity do they have over the medium and long term to change initial inequality and the balance between work and family? And, third, what are the social and policy determinants that drive variations between countries and policies?

Bibliography

Aguirre, Rosario and Fernanda Ferrari (2014), "La construcción del sistema de cuidados en el Uruguay: En busca de consensos para una protección social más igualitaria”, Políticas Sociales series, No. 192 (LC/L.3805), Santiago, Chile, Economic Commission for Latin America and the Caribbean (ECLAC).

Batthyany, Karina, Natalia Genta and Valentina Perrotta (2012), "La población uruguaya y el cuidado: Persistencias de un mandato de género. Encuesta nacional sobre representaciones sociales del cuidado: Principales resultados", Mujer y Desarrollo series, No. 117 (LC/L.3530), Santiago, Chile, Economic Commission for Latin America and the Caribbean (ECLAC).

Bentancor, Andrea and María Isabel de Martini (2012), Detrás de la puerta: Trabajo, roles de género y cuidado, Santiago, Chile, Comunidad Mujer.

Blofield, Merike (2012), Care Work and Class: Domestic Workers' Struggle for Equal Rights in Latin America, University Park, Pennsylvania, Penn State Press.

Blofield, Merike and Juliana Martínez Franzoni (2014), "Maternalism, co-responsibility and social equity: a typology of work-family policies", Social Politics, June.
CAIF (Centros de Atención Integral a la Primera Infancia y la Familia) (2008), El Plan CAIF, Montevideo, Secretaría Ejecutiva Plan CAIF. Cerutti, Ana and others (2008), Plan CAIF, 1988-2008, Montevideo, October.

Chioda, Laura (2011), Work and Family: Latin America \& Caribbean Women in Search of New Balance, Washington, D.C., World Bank.

Comité de Coordinación Estratégica de Infancia y Adolescencia (2010), "Estrategia Nacional para la Infancia y la Adolescencia (ENIA) 2010-2030. Plan de Acción 2010-2015”, Documento de Trabajo, Montevideo.

Cornia, Giovanni (2010), "Income distribution under Latin America's new left regimes", Journal of Human Development and Capabilities, vol. 11, No. 1, Taylor \& Francis, February.

Durán, María-Ángeles (2004), “Cómo conciliar trabajo y vida familiar? Un desafío colosal" [online] http://www.comfia.info/ index.php?modo=leer\&art=14814.

ECLAC (Economic Commission for Latin America and the Caribbean) (2013a), Social Panorama of Latin America, 2013 (LC/G.2580), Santiago, Chile. United Nations publication, Sales No. E.14.II.G.6. 
(2013b), Social Panorama of Latin America, 2012 (LC/G.2557-P), Santiago, Chile. United Nations publication, Sales No. E.13.II.G.6.

(2011), "Childcare and parental leave", Challenges: Newsletter on Progress Towards the Millenium Development Goals from a Child Rights Perspective, No. 12, Santiago, Chile, Economic Commission for Latin America and the Caribbean (ECLAC)/United Nations Children's Fund (UNICEF), July.

(2010), Social Panorama of Latin America, 2009 (LC/ G.2423-P), Santiago, Chile. United Nations publication, Sales No. E.09.II.G.135.

England, Paula and Nancy Folbre (1999), "The cost of caring", The Annals of the American Academy of Political and Social Science, vol. 561, No. 1, American Academy of Political and Social Science.

Esping-Andersen, Gøsta (2009), The Incomplete Revolution: Adapting to Women's New Roles, Cambridge, The Polity Press.

(1990), The Three Worlds of Welfare Capitalism, Cambridge, Polity Press.

Faur, Eleonor (2011), “A widening gap? The political and social organization of childcare in Argentina", Development and Change, vol. 42, No. 4, Wiley.

(2008), The "Care Diamond": Social Policy Regime, Care Policies and Programmes in Argentina, Geneva, United Nations Research Institute for Social Development (UNRISD).

Faur, Eleonor, Valeria Esquivel and Elizabeth Jelin (eds.) (2012), Las lógicas del cuidado infantil: Entre las familias, el Estado y el mercado, Buenos Aires, Institute of Economic and Social Development.

Filgueira, Fernando (2011), "Fault lines in Latin American social development and welfare regime challenges", The Great Gap: Inequality and the Politics of Redistribution in Latin America, Merike Blofield (ed.), College Park, Pennsylvania, Pennsylvania State University Press.

Folbre, Nancy (1995), "Holding hands at midnight: the paradox of caring labor", Feminist Economics, vol. 1, No. 1, Taylor \& Francis, February.

Fraser, Nancy (1997), Justice Interruptus: Critical Reflections on the "Postsocialist" Condition, London, Routledge.

Gherardi, Natalia, Laura Pautassi and Carla Zibecchi (2012), De eso no se habla: El cuidado en la agenda pública. Estudio de opinión sobre la organización del cuidado, Buenos Aires, Equipo Latinoamericano de Justicia y Género (ELA).

Goldin, Claudia (2006), "The quiet revolution that transformed women's employment, education, and family", American Economic Review, vol. 96, No. 2, Nashville, Tennessee, American Economic Association, January.

Government of Chile (2009), "Sistema de protección a la infancia: Chile Crece Contigo", Santiago, Chile.

Government of Costa Rica (2010), "Plan Nacional de Desarrollo 2010-2014”, María Teresa Obregón Zamora, San Jose, December.

Hirata, Helena and Nadya Araujo Guimarães (eds.) (2012), Cuidado e cuidadoras: As várias faces do trabalho do care, São Paulo, Editora Atlas.

Huber, Evelyne and John Stephens (2012), Democracy and the Left: Social Policy and Inequality in Latin America, Chicago, The Chicago University Press.

ILo (International Labour Organization) (2012), Panorama Laboral 2012. América Latina y el Caribe, Lima, ILo Regional Office for Latin America and the Caribbean.

(2011), Panorama Laboral 2010. América Latina y el Caribe, Lima, ILo Regional Office for Latin America and the Caribbean.

ILO/UNDP (International Labour Organization/United Nations Develoment Programme) (2009), Trabajo y familia: Hacia nuevas formas de conciliación con corresponsibilidad social, Santiago, Chile.
IMAS (Joint Institute for Social Aid) (2013), Monto de los subsidios para la participación en las diferentes alternativas de cuido y desarrollo infantil y directrices técnicas de cooperación, seps-022-1-13, San Jose, January.

Koven, Seth and Sonya Michel (1993), Mothers of a New World: Maternalist Politics and the Origins of Welfare States, New York, Routledge.

López-Calva, Luis and Nora Lustig (2010), Declining Inequality in Latin America: a Decade of Progress?, Washington, D.C., Brookings Institution.

Lupica, Carina (2013), Trabajo decente y cuidado compartido: Hacia una propuesta de parentalidad, Santiago, Chile, International Labour Organization (ILO)/United Nations Development Programme (UNDP).

Malajovich, Ana (2014), "La exclusión de los más vulnerables: Deudas educativas con la primera infancia”, Voces en el Fénix, No. 3, Buenos Aires, University of Buenos Aires.

Mancebo, Esther (2012), Personal Communication, 13 July.

Martínez Franzoni, Juliana and Rosalía Camacho (2007), "Equilibristas o malabaristas..., pero ¿con red? La actual infraestructura de cuidados en América Latina", Entre familia y trabajo: Relaciones, conflictos y políticas de género en Europa y América Latina, María Antonieta Carbonero and Silvia Levín (eds.), Rosario, Homo Sapiens Ediciones.

(2006), "Género, políticas conciliatorias y presupuesto público: Una aproximación al caso de América Latina y el Caribe", Cohesión social, políticas conciliatorias y presupuesto público. Una mirada desde el género, Luis Mora, María José Moreno and Tania Rohrer (coords.), Mexico City, United Nations Population Fund (UNFPA)/German Agency for Technical Cooperation (GTZ).

Martínez Franzoni, Juliana (2008), "Welfare regimes in Latin America: Capturing constellations of markets, families and policies", Latin American Politics and Society, vol. 50, No. 2, Wiley, June.

Martínez Franzoni, Juliana and Diego Sánchez-Ancochea (2013), "Public social goods and income inequality", A Primer on Labour Market Institutions and Inequality, Geneva, International Labour Organization (ILO), in press.

MIDEPLAN/MINSAL (Ministry of Planning/Ministry of Health) (2010), Cuatro años creciendo juntos. Memoria de la Instalación del Sistema de Protección Integral a la Infancia Chile Crece Contigo 2006-2010, Santiago, Chile.

Ministry of Education (2011), "Plano Nacional da Educaçao 2011-2020", Brasilia.

(2001), "Plano Nacional da Educaçao 2001", Brasilia.

Ministry of Social Development (2011), Plan Nacional de Acción por los Derechos de Niños, Niñas y Adolescentes 2012-2015, Buenos Aires.

Monge, Guillermo (2006), "Igualdad de género, pobreza y políticas de conciliación entre los ámbitos productivo y reproductivo y presupuestos públicos", Mexico City.

Montaño Virreira, Sonia (2010), "El cuidado en acción", El cuidado en acción: Entre el derecho y el trabajo, Cuadernos de la CEPAL series, No. 94 (LC/G.2454-P), Sonia Montaño and Coral Calderón Magaña (eds.), Santiago, Chile, Economic Commission for Latin America and the Caribbean (ECLAC). United Nations publication, Sales No. S.10.II.G.35.

Orloff, Ann Shola (2009), "Gendering the comparative analysis of welfare states: an unfinished agenda", Sociological Theory, vol. 27, No. 3, Wiley, September.

(2006), "Farewell to maternalism? State policies and mothers' employment", The State After Statism, Jonah Levy (ed.), Cambridge, Massachusetts, Harvard University Press.

Pautassi, Laura and Carla Zibecchi (2010), "La provisión de cuidado y la superación de la pobreza infantil. Programas de transferencias condicionadas en Argentina y el papel de las organizaciones sociales y comunitarias", Políticas Sociales 
series, No. 159 (LC/L.3198-P), Santiago, Chile, Economic Commission for Latin America and the Caribbean (ECLAC). United Nations publication, Sales No. S.10.II.G.10.

Pautassi, Laura and Nieves Rico (2011), "Childcare leave: a right of children and parents", Challenges: Newsletter on Progress Towards the Millenium Development Goals from a Child Rights Perspective, No. 12, Santiago, Chile, Economic Commission for Latin America and the Caribbean (ECLAC)/United Nations Children's Fund (UNICEF), July.

PNAD/IBGE (National Household Survey/Brazilian Geographical and Statistical Institute) (2014) [online] http://www. ibge. gov.br/home/estatistica/indicadores/trabalhoerendimento/ pnad_continua/default.shtm.

Presidency of the Federative Republic of Brazil (2009), "Emenda constitucional 59", 11 November.

Pribble, Jennifer (2013), Between Elites and the Masses: Political Parties and Welfare Regimes in Latin America, Cambridge, Cambridge University Press.

(2006), "The politics of women's welfare in Chile and Uruguay", Latin American Research Review, vol. 41, No. 2, Latin American Studies Association (LASA), December.

Ray, Rebecca, Janet Gornick and John Schmitt (2010), "Who cares? Assessing generosity and gender equality in parental leave policy designs in 21 countries", Journal of European Social Policy, vol. 20, No. 3, Sage.

Rodríguez, Corina and Laura Pautassi (coords.) (2014), La organización social del cuidado de niños y niñas: Elementos para la construcción de una agenda de cuidados en Argentina, Buenos Aires, Association for Civil Rights (ADC)/ Interdisciplinary Centre for Public Research (CIEPP)/Equipo Latinoamericano de Justicia y Género (ELA).

Román, Isabel and Natalia Morales (2010), "Demanda potencial de cuido infantil según estructura de los hogares: El caso de Costa Rica", San Jose.

Salvador, Soledad (2014), "Personal communication", Montevideo, 4 April.
(2013), “Análisis de costos y posibles impactos de diferentes modelos de licencias por maternidad, paternidad y parentales. Informe final de consultoría en el marco del proyecto URY2U503", Documento de Trabajo, 15 February.

(2010), "Hacia un Sistema Nacional de Cuidados en Uruguay", Montevideo, Economic Commission for Latin America and the Caribbean (ECLAC), 9 December.

Sauma, Pablo (2012), "Protección social y trabajo no remunerado: Redistribución de las responsabilidades y tareas del cuidado. Estudio de caso Costa Rica", Mujer y Desarrollo series, No. 116 (LC/L.3519), Santiago, Chile, Economic Commission for Latin America and the Caribbean (ECLAC).

Sojo, Ana (2011), "De la evanescencia a la mira: El cuidado como eje de políticas y de actores en América Latina", Seminarios y Conferencias series, No. 67 (LC/L.3393), Santiago, Chile, Economic Commission for Latin America and the Caribbean (ECLAC).

Sorj, Bila (2013), "Arenas de cuidado nas interseções entre género e classe social no Brasil", Cadernos de Pesquisa, vol. 43, No. 149, São Paulo, May-August.

Sorj, Bila and Adriana Fontes (2012), "O care como um regime estratificado: Implicações de género e classe social", Cuidado e cuidadoras. As várias faces do trabalho do care, Helena Hirata and Nadya Araujo Guimaraes (orgs.), São Paulo, Atlas.

Staab, Silke (2012), "Maternalism, male-breadwinner bias and market reform: historical legacies and current reforms in Chilean social policy", Social Politics, vol. 19, No. 3.

Waldmann, Lea and others (2011), Servicios de atención a niños y niñas de 45 días a 36 meses, Buenos Aires, United Nations Children's Fund (UNICEF).

Williams, Fiona (2010), "Claiming and framing in the making of care policies: the recognition and redistribution of care", Gender and Development Programme, No. 13, Geneva, United Nations Research Institute for Social Development (UNRISD), November. 